\title{
Faktor-Faktor Yang Mempengaruhi Partisipasi Anggota serta hubungannya dengan Keberhasilan Usaha Koperasi Wanita di Kabupaten Pasuruan
}

\author{
Ilfi Nur Diana
}

Dosen Fak. Ekonomi Universitas Islam Negeri (UIN) Malang, Aktif pada Pusat Studi Gender

\begin{abstract}
Abstrak
The purpose of this research is to reveal the factors which affect members participation of Kopwan in Pasuruan. And to analyze the simultaneous and the partial influences of these factors. This reseach also to analyze influences members participation on the increasing business success.

Hypotesis of this research are: (1) Social factors and economic factors affect positively the members participation of Kopwan, simultaneously or parsially. (2) Members participation affect positively the success bussiness of Kopwan in Pasuruan.

The population of this research is five Kopwan in Pasuruan, and the respondens are 84 members of all of Kopwan. The hypotesis are tested by Path Analysis. The results of this reseach are (1). Social factors) and economic factors affect positively the members participation of Kopwan, simultaneously or parsially. (2) Members participation affect positively the success bussiness of Kopwan in Pasuruan.

Therefore Kopwan must care and increase members education, specially about cooperation, increase bussiness which fit the need members, give a fit price and rate of
\end{abstract}


interest provitly. Managemen must do plan maximally and optimally, and collect obligatory saving on the agreed time with members of kopwan.

\section{A. Pendahuluan}

Pasal 33 UUD 1945 menyebutkan, "perekonomian disusun sebagai usaha bersama berdasarkan asas kekeluargaan". Penjelasan pasal tersebut menyatakan bahwa bangun perusahaan yang sesuai dengan itu adalah koperasi. Dengan demikian secara konstitusional, koperasi merupakan pelaksanaan kegiatan ekonomi selain BUMN dan BUMS.'

Mengingat pentingnya kedudukan koperasi tersebut, maka pertumbuhan dan perkembangannya perlu terus ditingkatkan, agar dapat mencapai tujuannya, yaitu menyejahterakan anggota. Hal ini sesuai dengan apa yang ditegaskan dalam Pasal 1 UU Nomor 25 Tahun 1992 tentang perkoperasian, bahwa koperasi bertujuan memajukan kesejahteraan anggota pada khususnya dan masyarakat pada umumnya serta ikut membangun tatanan perekonomian nasional dalam rangka mewujudkan masyarakat yang maju, adil, dan makmur berlandaskan Pancasila dan Undang-undang Dasar 1945. Hal ini berarti koperasi merupakan organisasi ekonomi yang bertujuan promosi anggota, dengan memperhatikan prinsip ekonomi dan bisnis secara seksama.

Namun demikian, koperasi masih belum dapat mengembangkan sepenuhnya potensi dan kemamapuannya dalam memajukan perekonomian nasional. Koperasi masih mempunyai kelemahan baik dalam bidang manajemen maupun permodalan. Koperasi masih mempunyai kelemahan-kelemahan, antara lain²:

1. Adanya pengetahuan anggota yang terbatas,

2. Kurangnya promosi produk yang dihasilkan,

3. Produk yang dihasilkan kurang layak jual, dan

4. Tidak memiliki modal yang kuat.

Kelemahan-kelemahan tersebut menjadi hambatan dalam mencapai keberhasilan. Salah satu cara koperasi menjadi kuat adalah dengan memberdayakan anggota untuk berpartisipasi. Bagaimanapun besarnya dedikasi 
pengurus dan pengelola serta tingginya pembinaan, tidak akan mencapai hasil yang maksimal tanpa adanya partisipasi anggota. Dengan demikian, keterlibatan anggota dalam kegiatan koperasi adalah berupa sumbangan tenaga, pikiran, dan pendanaan, sehingga menunjang keberhasilan koperasi.

Hal ini sesuai dengan apa yang diungkapkan oleh Jochen Ropke bahwa partisipasi anggota terdiri dari ${ }^{3}$ :

1. Partisipasi anggota dalam kontribusi modal atau mobilisasi sumberdaya,

2. Partisipasi anggota dalam pengambilan keputusan, dan

3. Partisipasi anggota dalam pemanfaatan pelayanan (benefit).

Ketiga partisipasi tersebut menurut Herman Suwardi merupakan partisipasi yang ideal. Koperasi didirikan berdasarkan kepentingan bersama dari anggotanya, modal juga dihimpun dan dipupuk bersama-sama. Semakin besar partisipasi anggota dalam pemupukan modal koperasi, akan semakin besar pula jumlah modal yang didapat oleh koperasi. Sebaliknya apabila partisipasi anggota dalam pemanfaatan pelayanan rendah, maka akan mempengaruhi struktur finansial dan volume usaha koperasi. ${ }^{4}$

Koperasi di Kabupaten Pasuruan sangat banyak, mencapai 413 buah, dengan rincian 70 KUD, 8 Kopwan, dan 335 koperasi lainnya, termasuk Kopkar, Kopontren, dan lain sebagainya. Kopwan di Kabupaten Pasuruan dari tahun ke tahun terus mengalami perkembangan, baik jumlah koperasi, anggota, modal, volume usaha, dan SHU. Namun demikian, perkembangan tersebut hanya untuk beberapa koperasi saja, sementara koperasi yang lain belum berkembang dengan baik. Adapun permodalannya, sebagian besar masih berasal dari modal luar. Ini menunjukkan kurangnya partisipasi anggota dalam permodalan. Hal tersebut berakibat koperasi mempunyaibeban biayayang lebih besar. Besar kecilnya biaya ini juga akan mempengaruhi SHU, oleh sebab itu dalam beroperasi, biaya harus dapat ditekan seminimal mungkin.

Kemampuan Koperasi Wanita (Kopwan) menghasilkan SHU dari modal sendiri juga masih sangat kecil. Hal ini dapat dilihat dari nilai Return on Equity (ROE). Nilai rata-rata ROE hanya mencapai 4,6\%. Hal ini berarti nilai ROE nya masih réndah dari nilai tingkat bunga yang berlaku di pasar. Hal ini patut diduga disebabkan oleh rendahnya partisipasi anggota dalam memanfaatkan pelayanan. 


\section{B. Rumusan Masalah}

1. Bagaimana pengaruh faktor sosial dan ekonomi terhadap partisipasi anggota dalam permodalan dan pemanfaatan pelayanan Koperasi Wanita.

2. Bagaimana pengaruh partisipasi anggota dalam permodalan dan pemanfaatan pelayanan terhadap keberhasilan usaha Koperasi Wanita.

\section{Metode Penelitian}

Objek dari penelitian ini adalah faktor-faktor yang mempengaruhi partisipasi anggota dalam meningkatkan keberhasilan usaha pada Kopwan di Kabupaten Pasuruan. Faktor-faktor tersebut adalah faktor sosial yang meliputi pendidikan, kepercayaan, rasa memiliki, lamanya keanggotaan, dan faktor ekonomi yang meliputi pendapatan, kesesuaian pelayanan, jarak, dan jumlah anggota keluarga. Sedangkan partisipasi anggota yang dimaksud di sini adalah partisipasi anggota dalam permodalan dan pemanfaatan pelayanan.

Metode penelitian yang digunakan adalah sensus dan bersifat non eksperimental dan bentuk penelitiannya adalah penelitian penjelasan (explanatory research) karena untuk menjelaskan hubungan kausal antar variabel melalui pengujian hipotesis

Untuk memperoleh data yang diperlukan, dilakukan dengan wawancara. Dan analisis yang digunakan adalah analisis kuantitatif, berupa pengujian hipotesis dengan menggunakan analisis jalur (Path Analysis.) Sebelum melakukan analisis jalur, terlebih dahulu dijelaskan mengenai hubungan antar variable secara diagramatik (diagramjalur) yang bentuknya ditentukan oleh proporsi teoritik yang berasal dari kerangka pemikiran tertentu dan perumusan hipotesis penelitian.

Hipotesis penelitian diperlihatkan melalui strukturhubungan antara variabel independen dengan variabel dependen dengan diagram jalur seperti pada gambar berikut ini : 


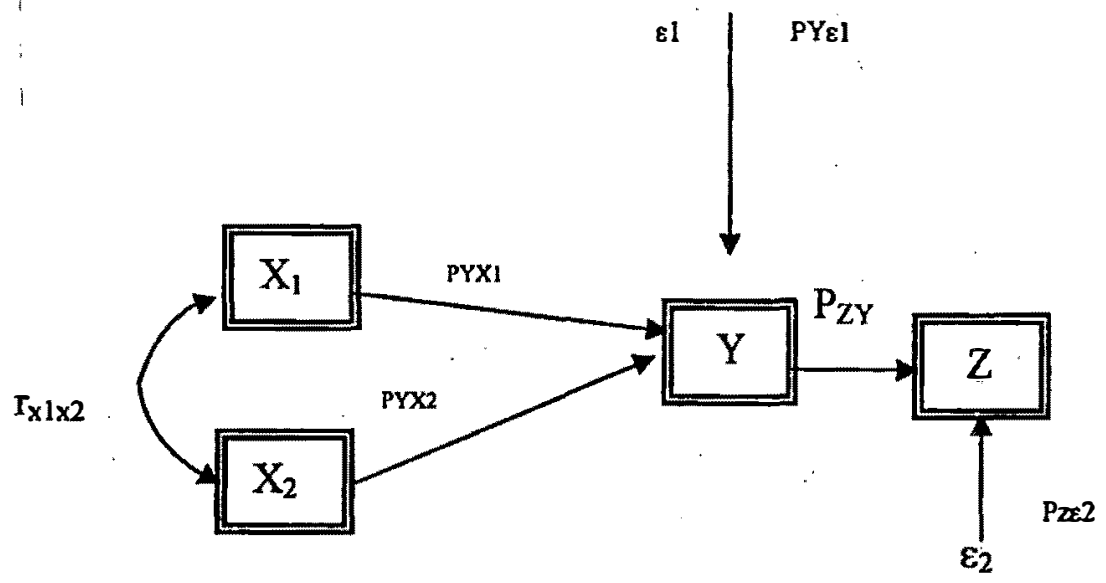

Gambar 1. Hubungan Kausal Antara Variabel $X_{1}, X_{2}, Y$ dan Z

Adapun populasi dalam penelitian ini adalah Kopwan yang ada di kabupaten Pasuruan. Dan Kopwan yang dipilih adalah Kopwan yang sudah RAT yang keseluruhannya berjumlah enam unit, dan karena ada yang ekstrim maka ada yang dikeluarkan satu, sehingga yang diteliti ada lima. Agar setiap koperasi meinilikj peluang yang sama untuk menjadi anggota sampel, maka sampel (n) yang dapat dijadikan responden diambil dengan menggunakan Sampel random samplinguntuk anggota diperoleh sebanyak 84 anggota $^{5}$,

\section{Partisipasi Anggota}

Menurut Hanel, dimensi-dimensi partisipasi anggota dalam hubungannya dengan prinsip identitas ganda, adalah:

\section{Sebagai pemilik.}

Ainggota harus memberikan kontribusi terhadap pembentukan dan pertumbuhan usaha koperasi dalam kontribusi modal serta mengambil bagian dalam 
penetapan tujuan, pembuatan keputusan dan dalam proses pengawasan terhadap tata kehidupan koperasi.

\section{Sebagai pelanggan.}

Anggota memanfaatkan berbagai potensi yang disediakan oleh koperasi untuk menunjuang kepentingan dan kebutuhannya. ${ }^{6}$

Dalam berpartisipasi, anggota mempunyai motifasi baik motifasi ekonomi ataupun sosial. Sejalan dengan hal tersebut Ropke mengemukakan, bahwa kualitas partisipasi tergantung pada interaksi tiga variabel, yaitu para anggota, manajemen koperasi dan program. ${ }^{7}$ Dari ketiga variabel tersebut harus terdapat kesesuaian, yaint:

1. Kesesuaian antara program yang dikeluarkan oleh koperasi dengan kebutuhan dan keinginan para anggotanya,

2. Kesesuaian antara permintaan anggota dengan keputusan-keputusan pelayanan koperasi, dan

3. Kesesuaian antara tugas program koperasi dengan kemampuan manajemen koperasi.

\section{Program}

Model kesesuaian tersebut dapat digambarkan sebagai berikut:

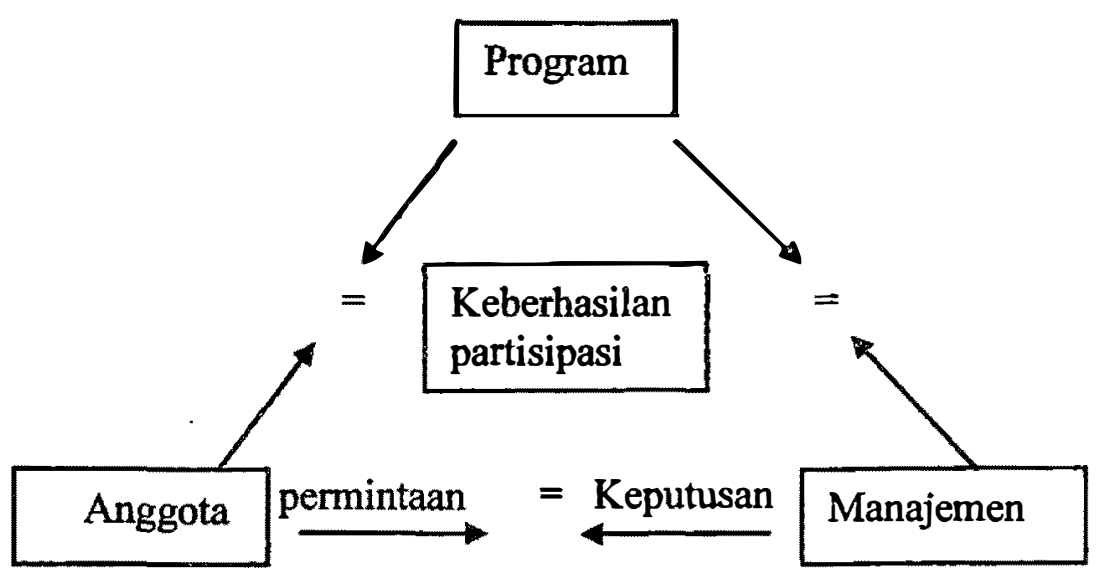

Ulul Albab, Vol. 6 No. 1, 2005 
Gambar 2. Model Kesesuaian Partisipasi

Ketiga kesesuaian tersebut berkaitan dengan utility (keuntungan, keunggulan, kelebihan) yang diperoleh dari koperasi. Semakin besar manfaat yang diterima oleh anggota, semakin besar partisipasi anggota dan akan memenuhi kewajibannya.

Dari uraian tersebut di atas dapat dikemukakan bahwa faktor yang menentukan partisipasi anggota tergantung dari potensi sosial ekonomis anggota itu sendiri, hal ini dapat dijabarkan sebagai berikut:

1. Faktor sosial:

a. Pendidikan.

b. Kepercayaan.

c. Rasa memiliki.

d. Lamanya keanggotaan.

2. Faktor ekonomi:

a. Pendapatan keluarga.

b. Kesesuaian pelayanan.

c. Jarak.

d. Imbalan jasa.

e. Jumlah anggota keluarga.

\section{E. Keberhasilan Usaha Koperasi}

Keberhasilan koperasi adalah terwujudnya tingkat efisiensi pelayanan yang optimal bagi anggota, dengan kata lain anggota koperasi dapat merasakan manfaat jasa pelayanan yang dihasilkan koperasi. Menurut Ima Suwadi, keberhasilan koperasi dapat dilihat sebagai berikut:

1. Keberhasilan koperasi, yang meliputi perkembangan anggota, administrasi, pengurus, badan pemeriksa, badan pembimbing dan pelindung.

2. Keberhasilan usaha, yang meliputi volume usaha, kekuatan modal, kemampuan memupuk modal, sisa hasil usaha (SHU), bagian SHU yang diterima oleh anggota. 
3. Keadaan keuangan, yang tergambar dalam laporan keuangan (neraca, laporan laba rugi, laporan arus kas dan catatan atas laporan keuangan). ${ }^{8}$

Dengan demikian keberhasilan koperasi ditentukan oleh beberapa variabel. Dalam penelitian ini, untuk menilai keberhasilan koperasi mengacu pada keberhasilan dari segi usaha yang meliputi:

1. Modal.

Untuk melayani anggota sebagai pemakai jasa koperasi, maka idealnya sumber modal diperoleh dari modal sendiri, sedangkan modal asing dipergunakan jika keberadaannya ternyata dapat meningkatkan rentabilitas usaha bagi koperasi. 2. Volume Usaha.

Volume usahaadalah total nilai penjualan atau penerimaan dari barang dan atau jasa pada suatu periode waktu tertentu.

3. SHU.

SHU koperasi adalah selisih dari seluruh pendapatan atau penerimaan total dengan biaya-biaya yang dikeluarkan oleh koperasi dalam satu tahun buku. Adapun besarnya SHU yang diterima oleh setiap anggota akan berbeda, tergantung besarnya partisipasi dalam permodalan dan pemanfaatan pelayanan. ${ }^{9}$

\section{F. Hasil dan Pembahasan}

Uji hipotesis penelitian ini menggunakan analisis jalur yang berdasarkan pada koefisien korelasi melalui paket program Microsoft Excell for Windows. Hasil penelitian yang diperoleh, kemudian dilakukan analisis untuk mengetahui besarnya pengaruh faktor-faktor yang mempengaruhi efisiensi finansial dalam meningkatkan keberhasilan usaha baik secara simultan maupun secara parsial.

Berdasarkan hasil penelitian yang kemudian diolah dengan menggunakan analisis jalur, hasilnya dapat diketahui bahwa pengaruh variabel faktor sosial sebesar $92.65 \%$, faktor ekonomi sebesar $1.16 \%$. Jadi secara simultan faktor sosial dan faktor ekonomi mampu menerangkan $93.81 \%$ variasi partisipasi anggota, sedangkan sisanya $6.19 \%$ diterangkan oleh variabel lain. Hal ini signifikan dengan 
uji $F$, yang mana $F$ hitung $>F$ tabel. $F$ hitung sebesar19,0000, $F$ tabel sebesar 15,1638 dengan taraf kesalahan $5 \%$.

Uji hipotesis penelitian secara parsial tentang faktor sosial dan faktor ekonomi yang mempengaruhi partisipasi anggota dalam permodalan dan pemanfaatan pelayanan, menggunakan analisis jalur, yaitu:

\section{Variabel Faktor sosial (X1)}

Besarnya pengaruh variabel faktor sosial (X1) terhadap partisipasi anggota dalam permodalan dan pemanfaatan pelayanan, baik langsung maupun tidak langsung sebesar $91.67 \%$, sedangkan pengaruh tidak langsung melalui Faktor ekonomi (X2) sebesar $0.98 \%$. Hasil yang diperoleh dari pengujian hipotesis secara parsial menunjukkan bahwa pengaruh Faktor sosial (X1) terhadap partisipasi anggota dalam permodalan dan pemanfaatan pelayanan $(\mathrm{Y})$ sebesar $92.65 \%$. Hal ini signifikan dengan uji $\mathrm{T}$, yang mana nilai thitung $>t$ tabel. T hitung 5,2872 , sedangkan $t$ tabel 4, 3027 dengan taraf kesalahan $5 \%$.

\section{Variabel Faktor Ekonomi (X2)}

Besamya pengaruh variabel faktor ekonomi (X2) terhadap partisipasi anggota dalam permodalan dan pemanfaatan pelayanan secara parsial, baik langsung maupun tidak sebesar $0.18 \%$, sedangkan pengaruh tidak langsung melalui faktor sosial (Xl) sebesar $0.98 \%$. Hasil yang diperoleh dari pengujian hipotesis secara parsial menunjukkan bahwa pengaruh faktor ekonomi (X2) terhadap partisipasi anggota dalam permodalan dan pemarifaatan pelayanan $(\mathrm{Y})$ sebesar $1.16 \%$. Hal ini non signifikan dengan uji T, yang mana nilai t hitung 0,2366 , sedangkan $t$ tabel 4,3027.

Pengaruh secara parsial tersebut dapat diartikan bahwa apabila faktor sosial (X1) meningkat maka Partisipasi anggota akan meningkat. Apabila faktor ekonomi (X2) meningkat maka partisipasi anggota akan meningkat walaupun keterkaitannya sangat kecil, dan hal ini mungkin terjadi.

Adapun hipotesis yang kedua, mengenai pengaruh partsisipasi anggota terhadap keberhasilan usaha Kopwan, menunjukkan bahwa partisipasi anggota dalam permodalan dan pemanfaatan pelayanan mampu menerangkan $66.40 \%$ variasi keberhasilan usaha, sedangkan sisanya $33.60 \%$ diterangkan oleh variabel 
lain. Hal tersebut non signifikan, yang mana thitung sebesar 2.4361, sedangkan $t$ tabel sebesar 3,1824.

Secara keseluruhan dapat digambarkan dalam skema berikut :

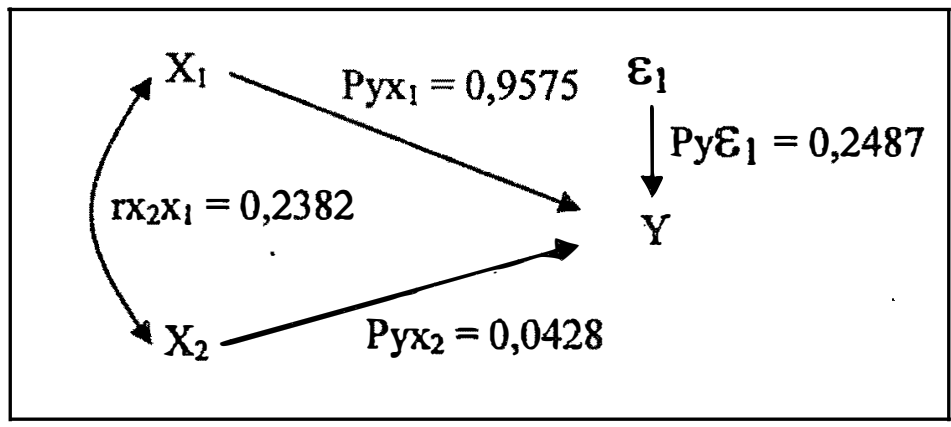

Gambar 3. Sub struktur 1, antara variabel $\mathrm{X} 1, \mathrm{X} 2$ dengan $\mathrm{Y}$

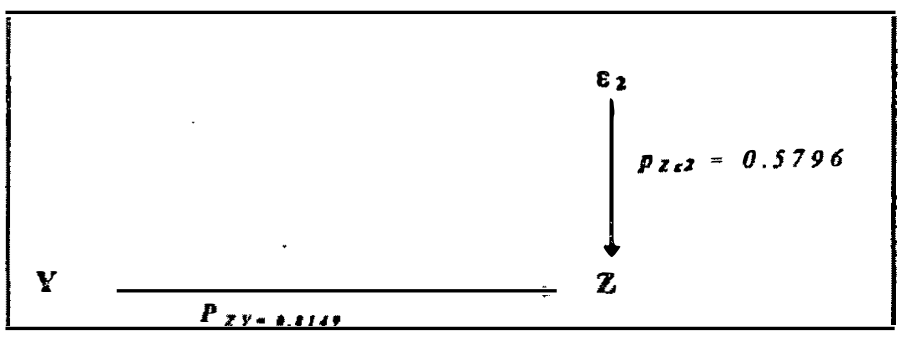

Gambar 4. Sub struktur2, antara variabel $Y$ dengan variabel $Z$

Adapun variabel lain adalah tingkat persaingan, bantuan pemerintah, pengembangan usaha, dan kinerja Manajer. Hal ini seperti penelitian yang telah dilakukan oleh Harsono tentang faktor-faktor yang menentukan keberhasilan usaha koperasi di Kabupaten Malang Jawa Timur, ia berhasil mengungkapkan bahwa faktor yang dipandang penting menentukan keberhasilan usaha koperasi adalah tingkat persaingan, kinerja manajer, dan bantuan pemerintah ${ }^{10}$. Begitu pula penelitian yang dilakukan oleh Muslimin Nasution (1990), di samping partisipasi anggota keberhasilan usaha KUD temyata dipengaruhi secara positif oleh potensi pengembangan usaha" 


\section{G Pembahasan}

Uji hipotesis sub struktur 1 adalah variabel Xi Secara simultan, mempunyai pengaruh yang positif terhadap variabel $Y$. Hasilnya menunjukkan bahwa pengaruh variabel faktor sosial dan ekonomi sebesar $93.81 \%$. Hal ini berarti faktor Xl (Faktor sosial) dan X2 (faktor ekonomi) pengaruhnya positif dan signifikan.Apabila faktor sosial dan ekonomi diperhatikan dengan baik, maka Y (partisipasi anggota) akan meningkat.

Adapun pengujian hipotesis secara parsial adalah:

1. Pengaruh Faktor sosial (X1) terhadap partisipasi anggota (Y).

Hasil yang diperoleh dari pengujian hipotesis secara parsial menunjukkan bahwa pengaruh Faktor sosial (XI) terhadap partisipasi anggota dalam permodalan dan pemanfaatan pelayanan $(Y)$ sebesar $92.65 \%$. Hal ini berarti faktor sosial berpengaruh positif dan signifikan terhadap partisipasi anggota dalam permodalan dan pemanfaatan pelayanan, sehingga pengaruh tersebut tidak dapat diabaikan. Semakin tinggi faktor sosial maka akan semakin tinggi partisipasi anggota dalam permodalan dan pemanfaatan pelayanan.

2. Pengaruh Faktor ekonomi (X2) terhadap partisipasi anggota ( $\mathrm{Y}$ )

Hasil yang diperoleh dari pengujian hipotesis secara parsial menunjukkan bahwa pengaruh Faktor ekonomi (X2) terhadap partisipasi anggota dalam permodalan dan pemanfaatan pelayanan $(\mathrm{Y})$ sebesar $1.16 \%$. Hal ini berarti faktor ekonomi berpengaruh positif walaupun pengaruhnya sangat kecil (non signifikan) terhadap partisipasi anggota dalam permodalan dan pemanfaatan pelayanan, hal ini tidak dapat diabaikan begitu saja. Oleh sebab itu semakin tinggi faktor ekonomi, dimungkinkan semakin tinggipartisipasi anggota dalam permodalan dan pemanfaatan pelayanan.

Uji hipotesis untuk substruktur 2 (dua) menunjukkan pengaruh partisipasi anggota $(Y)$ terhadap keberhasilan usaha sebesar $66.40 \%$, dan mempunyai arah yang positif terhadap keberhasilan usaha. Ini berarti, apabila partisipasi anggota dalam permodalan dan pemanfaatan pelayanan besar, maka keberhasilan usaha 
akan semakin besar. Oleh sebab itu dalam meningkatkan keberhasilan usaha, faktor partisipasi anggota tidak dapat diabaikan.

Adapun besarnya pengaruh masing-masing sub variabel dari faktor sosial dan ekonomi adalah sebagai berikut:

1. Pengaruh total X1.1 (Pendidikan) sebesar $2,48 \%$.

2. Pengaruh total $X 1.2$ (Kepercayaan pada manajemen) sebesar $4,79 \%$.

3. Pengaruh total $X 1.3$ (Rasa memiliki) sebesar $18,45 \%$.

4. Pengaruh total X1.4 (Lamanya keanggotaan) sebesar $16,60 \%$.

5. Pengaruh total X2.1 (Pendapatan) sebesar $2,99 \%$.

6. Pengaruh total $\mathrm{X} 2.2$ (Kesesuaian pelayanan) sebesar $3,84 \%$.

7. Pengaruh total X2.3 (Kemudahan jangkauan) sebesar $1,36 \%$.

8. Pengaruh total $\mathrm{X} 2.4$ (Jumlah anggota keluarga) sebesar 0,71

\section{H. Kesimpulan}

Berdasarkan hasil penelitian dan analisis yang dilakukan dapat dikemukakan kesimpulan sebagai berikut:

1. Faktor sosial (Kepercayaan pada pihak manajemen, lamanya keanggotaan, rasa memiliki, pendidikan anggota baik formal maupun tentang perkoperasian) dan faktor ekonomi (Tersedianya pinjaman, kemudahan jangkauan, kesesuaian harga, jumlah anggota keluarga, pendapatan, tersedianya barang, bunga pinjaman), secara simultan berpengaruh positif dan signifikan terhadap partisipasi anggota dalam permodalan dan pemanfaatan pelayanan pada Koperasi Wanita di kabupaten Pasuruan.

2. Pengaruh masing-masing faktor sosial dan ekonomi tersebut adalah sebagai berikut:

a. Faktor sosial berpengaruh positif dan signifikan terhadap partisipasi anggota dalam permodalan dan pemanfaatan pelayanan.

b. Faktor ekonomi berpengaruh positif dan non signifikan terhadap partisipasi anggota dalam permodalan dan pemanfaatan pelayanan. 
3. Pengaruh masing-masing sub variabel dari faktor sosial dan ekonomi adalah pendidikan dan kepercayaan pada manajemen berpengaruh positif dan non signifikan, rasa memiliki berpengaruh positif dan signifikan, dan lamanya keanggotaan berpengaruh positif dan signifikan. Adapun pendapatan dan kesesuaian pelayanan berpengaruh positif dan non signifikan, begitu juga kemudahan jangkauan berpengaruih positif dan non signifikan, sedangkan jumlah anggota keluarga berpengaruh positif dan signifikan.

4. Partisipasi anggota dalam permodalan dan pemanfaatan pelayanan berpengaruh positif terhadap keberhasilan koperasi wanita di Kabupaten Pasuruan.

\section{Saran}

Berdasarkan kesimpulan, maka saran-saran yang dapat penulis ajukan adalah, Kopwan di Kabupaten Pasuruan hendaknya:

1. Melakukan kerja sama dengan instansi terkait untuk mengadakan pelatihan tentang perkoperasian bagi anggota, atau juga lebih mengintensifkan pelatihan. Kopwan juga dapat meningkatkan pendidikan anggota tentang perkoperasian dengan cara memberikan brosur mengenai perkoperasian pada anggota secara bertahap. Dan yang tak kalah pentingnya mengikutsertakan pengurus dalam pembinaan pengembangan usaha.

2. Pengurus hendaknya melaksanakan program kerja secara optimal, baik dalam bidang organisasi, administrasi, usaha, dan keuangan, agar kepercayaan anggota pada pengurus dapat berjalan efektif untuk kemajuan Kopwan.

3. Melakukan penagihan atau pembayaran kolektif atas simpanan wajib pada anggota tiap bulan, atau melakukan kesepakatan terlebih dahulu dengan anggota mengenai cara pembayaran simpanan wajib, perbulan ataukah pertiga bulan.

4. Meningkatkan usaha yang lebih variatif sesuai kebutuhan anggota, atau juga Menambah stok barang yang dijual atau yang disewakan agar tidak sampai kehabisan. Begitu pula dengan Kopwan Lestari Makmur dan Rana Puri hendaknya dapat menambah unit usaha dagang, mengingat kedua koperasi tersebut jauh dari pasar dan pertokoan. 
5. Dalam menentukan harga hendaknya lebih murah atau minimal sama dengan harga pasar, karena itu Kopwan hendaknya dapat menembus langsung ke produsen agar lebih banyak mendapat keuntungan. Adapun bunga pinjaman hendaknya tidak melebihi bunga Bank, dan bunga simpanan minimal sama dengan bunga Bank. Oleh sebab itu modal yang dipergunakan hendaknya berasal dari modal sendiri.

Variabel lain yang tidak termasuk dalam penelitian ini antara lain tingkat persaingan, bantuan pemerintah, kinerja manajer, potensi pengembangan usaha hendaknya dapat diteliti oleh peneliti lain yang ingin melakukan penelitian lebih mendalam mengenai Keberhasilan usaha koperasi

\section{Endnotes}

1 UUD 1945

2 Surahman Sumawiharja Aspek-aspek Manajemen Usaha Koperasi sebagai Pedoman Pengembangan Kebijakan Koperasi di Indonesia, Unpad, Bandung, 1988:30

3 Jochen Ropke Strategi menuju Keswadayaan Koperasi, Badan Penelitian dan Pengembangan Koperasi Depkop, 1989:82

s Herman Suwardi, Menuju ke Arah Pola Partisipasi yang ideal, dalam Khoiru Djamhari Ke Arah Pemahamana Bangun Perusahaan Koperasi, Badan Penelitian dan Pengembangan Koperasi, Jakarta, 1985:396

5 Harun al-Rasyid, Teknik Penarikan Sampel dan Penyusunan Skala, Program Pasca Sarjana Unpad, Bandung, 1993

- Hanel, Organisasi Koperasi, Pokok-pokok Pikiran mengenai Organisasi Koperasi dan Kebijaksanaan Pengembangan di Negara-negara Berkembang, Edisi I, Unpad, Bandung 1989:60

7 Ropke, Teori Ekonomi Koperasi, alih bahasa Hj.Sri Djatnika, Salemba Empat, Jakarta, 2000.(2000:62

8 Ima Suwadi, Daya Guna dan Hasil Guna pada Koperasi, Dalam era Efisiensi Nasionai, Choirul Jamhari(Ed), Balitbangkop Depkop, Jakarta, 1988:286

9 Arifin Sitio, Koperasi, Teori dan Praktek, Erlangga, jakarta 2001:87

10 Harsono, Faktor-faktor yang Menentukan Keberhasilan Usaha Koperasi di Kabupaten Malang, Tesis, UGM, Yogjakarta, 1985

"Muslimin Nasution, Keragaan KUD sebagai Organisasi Ekonomi Pedesaan, Disertasi, IPB, Bogor, 1990 


\section{Bibliography}

Arifin Sitio dan Halomoan Tamba, Koperasi,Teori dan Praktek, Erlangga, jakarta, 2001.

Dinas Koperasi, Usaha kecil dan Menengah Kab. Pasuruan, Daftar Riil KUD/ Koperasi Kabupaten Pasuruan.

Hanel, Alfred, Organisasi Koperasi, Pokok-pokok Pikiran mengenai Organisasi Koperasi dan Kebijaksanaan Pengembangan di Negaranegara Berkembang, Edisi I, Unpad, Bandung, 1989.

Harsono, Faktor-faktor yang Menentukan Keberhasilan Usaha Koperasi di Kabupaten Malang, Tesis, UGM, Yogjakarta.

Harun al-Rasyid, Teknik Penarikan Sampel dan Penyusunan Skala, Program Pasca Sarjana Unpad, Bandung, 1993.

Herman Suwardi, Menuju ke Arah Pola Partisipasi yang ideal, dalam Khoiru Djamhari Ke Arah Pemahamana Bangun Perusahaan Koperasi, Badan Penelitian dan Pengembangan Koperasi, Jakarta, 1985.

Ign Sukamdiyo, Manajemen Koperasi, Erlangga, Jakarta, 1996.

Ima Suwadi, Daya Guna dan Hasil Guna pada Koperasi, Dalam era Efisiensi Nasional, Choirul Jamhari (Ed), Balitbangkop Depkop, Jakarta, 1986.

Kuhn, Johanes, Cooperative Organizations For Rural Development Organizational and management Aspect, Marbug-Bandung, 1987

Masri Sangarimbun, Sofyan Effendi, Metode Penelitian Survei, LP3ES, Jakarta, 1988.

Mukner,H., Cooperative Principles and Cooperative Law, Friedrich, Effort, Stiftung, Bonn, 1985.

Muslimin Nasution, Keragaan KUD sebagai Organisasi Ekonomi Pedesaan, Disertasi, IPB, Bogor.

Nirwana SK.Sitepu, Analisis Jalur (Path Analisis), Unit pelayanan statistika jurusan Statistik, F.Mipa Unpad, Bandung 1994. 
Ropke, Jochn, Strategi menuju Keswadayaan Koperasi, Badan Penelitian dan Pengembangan Koperasi Depkop, 1989.

- , Teori Ekonomi Koperasi, alih bahasa Hj.Sri Djatnika, Salemba Empat, Jakarta, 2000.

Saleh Safraji, Pemikiran Modernisasi KUD, Pendekatan Lembaga-lembaga Usaha, Jakarta, 1988

Santoso Sastropoetro, Partisipasai Komunikasi, Persuasi dan Disiplin dalam Pembangunan Nasional, Alumni, Bandung, 1988

Siegel, Sidney, Statistik Non Parametrik untuk Ilmu-Ilmu Sosial, PT Gramedia, Jakarta, 1997.

Soejono, Gerakan Menuju Sistem Koperasi Kredit yang Efektif, BK3I, Jakarta, 1995

Sugiono, Metode Penelitian Bisnis, W Alfabeta, Bandung, 1999

Surahman Sumawiharja, Aspek-aspek Manajemen Usaha Koperasi sebagai Pedoman Pengembangan Kebijakan Koperasi di Indonesia, Unpad, Bandung, 1988.

Sutaryo Salim, Kebijaksanaan Pembangunan dan Promosi Koperasi, BKU Ilmu Ekonomi Koperasi, 1996.

Thoby Mutis, Pengembangan Koperasi, Grasindo, Jakarta, 1992.

- Pendekatan Ekonomi Pengetahuan dalam Manajemen Kodertiminasi, Jurus Jitu Memenangkan Persaingan, PT Gramedia Widia Sarana indonesia, 1995.

Yuyun Wirasasmita, Strategi Pembangunan Sektor Perkoperasian yang Dapat Menggerakkan Partisipasi Masyarakat dalam Perkoperasian, Bunga Rampai, Pokok-pokok Pikiran tentang tentang Pembangunan Koperasi, Ikopin, 199.

Depkop RI, Undang-Undang republik Indonesia Nomer 251992 tentang Perkoperasian.

UUD Republik Indonesia 1945.

Andang K ardiwidjaya, Pengukuran Keberhasilan Koperasi Dilihat dari Sudut Anggota, dalam Jurnal Value FMK, Ikopin, Bandung, 2000.

Suwandi, Citra Koperasi Indonesia, dalam Pikiran rakyat, 12 Juli 2001. 